\title{
Introduction
}

\section{Implementing Disability Rights in National Contexts: Norms, Diffusion, and Conflicts}

\author{
Yohann Aucante* and Pierre-Yves Baudot** \\ *EHESS-CESPRA, Paris \\ E-mail: yohann.aucante@ehess.fr \\ **UPJV-CERAPS, Amiens \\ E-mail: pierre-yves.baudot@u-picardie.fr
}

This introductory article offers an analytical framework to understand the limits of approaches that stress the diffusion and transfers of international norms within the field of disability policy over the last three decades. It also aims to provide alternative ways to frame some of the important changes that have occurred through the concept of layering, in order to better account for the intricate processes of national translation but also for the contradictions, conflicts, and obstacles that the promotion of disability rights have faced in different countries. Finally, this article serves to introduce the contributions that make up the themed section in this issue of Social Policy and Society.

Keywords: Disability policy, rights, diffusion, layering, social welfare.

\section{Introduction}

The literature on public policies intended for people with disabilities emphasises the importance of the international circulation of ideas and its consequences for policy design at the national level. The American civil rights model best exemplified by the 1990 Americans with Disabilities Act (ADA) is said to have gradually spread across the world of developed welfare states and even beyond, through well documented mechanisms. Influencing the 2006 United Nations Convention on the Rights of People with Disabilities and via disability activists from different countries, it is said to have had a decisive impact on the legal framework of diverse states from France, to Scandinavia and Japan, but also the Global South. Two main issues are at the heart of this literature: on the one hand, international and transnational processes of diffusion of ideas and norms; on the other hand, national or regional (EU) forms of implementation of policies and rights. The first one is related to the timing and forms of conversion of national policies into what is considered to be pathbreaking international standards, a kind of 'paradigm shift' (Harpur, 2012; Mittler, 2015) or a basis for a new definition of human rights (Mégret, 2008). The second one deals with the intensity and extent of this conversion, assessing the resistance that new norms face in different national contexts. However, academics and experts alike tend to neglect the fact that these processes are not necessarily black or white, that they are highly susceptible to layering of old and new - potentially conflicting - norms, legislations, and policies, and that there is room for different interpretations of the impact of new international standards. 
This introductory article aims to evaluate the contributions and limits of the paradigm of diffusion in the case of disability policies, and to understand how and why it came to prevail. It will also plead for a more situated sociology of public policies, showing how diverging legal and normative orders can coexist, even when they are potentially conflicting, and the result of this.

More precisely, three main sets of questions may be asked, that this introduction article will review briefly:

1. Do we see a gradual replacement of old national norms and doctrines by new standards and a real convergence of public policies and legislation (Hvinden, 2003), something closer to a hybrid of national policies with new forms or some kind of layering (Mahoney and Thelen, 2009)?

2. If the latter hypothesis of layering is verified (Heyer, 2002), how does this work in the actual policy and legal process of implementation? How can different possibly conflicting - legal definitions and approaches of disability be put to work simultaneously? What contradictions do policy-makers, administrators, legal actors or even citizens face and what do they do about them?

3. How can we account for differentiated modes of diffusion of international norms across and within countries when there seems to be at the same time a convergence of larger public policy doctrines in this domain?

\section{Advancing and translating rights}

The rights of people with disabilities in the contemporary era have been defined at the international level starting from the decisive influence of the 1990 Americans with Disabilities Act up to the 2006 Convention on the Rights of People with Disabilities, through the spreading of ideas and norms related to a 'social model of disability', as well as policy-learning and diffusion. These channels of change have been documented in a growing literature that stresses how the frameworks of rights evolve and are constantly reformulated, and how they travel across the world (Kelemen and Vanhala, 2010; Kelemen, 2011; Sabatello and Schulze, 2013; Heyer, 2015; Halvorsen et al., 2017). Several scholars and experts have also documented how these very processes of diffusion of international norms can be more or less hindered, leading to partial convergence or situations characterised as 'backwardness' (Lang et al., 2011; Chiriacescu et al., 2015; Fillion et al., 2015).

The objective of this themed section will be to take issue with the analytical framework that mainly builds on the idea of diffusion. Thus we intend to place the emphasis on the more concrete forms of public action, or lack thereof, at the national/local levels, and on the potential conflicts triggered by the coexistence and layering of different legal norms at multiple levels. This could be a pragmatic way to recast how disability rights actually evolve and are redefined, even in the U.S which is not immune to this kind of phenomenon.

Produced in a U.S context where civil rights may serve as a basis for the development of social rights, in part because of the weakness of other guarantees and social protection, the 'social model' of rights has certainly deeply influenced how we think of the 'rights' of people with disabilities (Engel and Munger, 2003; Nussbaum, 2007; Oliver and Barnes, 2012) but has also somewhat confused a critique of how people are (mis)treated - as 
citizens and as human beings, with a critique of how welfare states actually work (or should be reformed). We believe it is important to try to tackle this problem, starting from an analysis of the tensions and unresolved difficulties that international norms have created or stimulated in national legal and legislative settings, as well as in public policy processes.

In her seminal book, The Disabled State, Deborah A. Stone studied how the category of disability, relying on medical certification, had expanded in the realm of the modern welfare state, leading to a host of benefits - such as early pension programs -, exemptions and special treatments, while not eliminating the risk of stigma, dependence or disadvantage. Between 1960 and 1970, the number of beneficiaries of long-term disability programs had nearly doubled in the U.S (Stone, 1984: 7). This broad, political and administrative vision of disability as unexceptional in a life course had the double merit to document the myriad of compensatory programs that existed in the U.S and Europe but also to remind how tightly weaved in the welfare state matrix they had become. In spite of medical and epidemiological assessments of disability, its scope and legitimacy seemed to vary a lot from country to country. At the same time, Stone was writing in an age of growing criticism of public social welfare spending that allegedly opened for the curtailing of benefits and tightening of eligibility criteria within many social welfare programs. However, this 'retrenchment' did not affect all welfare regimes and disability policies in the same way (Pierson, 2002; Wilensky, 2002). If the U.S took the path of a bipartisan legislation on social rights of people with disabilities to fight discrimination after the ADA was passed in 1990, and if this model is believed to have spread internationally, the heritage of previous disability policies and the kind of norms they embodied have certainly not disappeared altogether.

In the U.S, not only did the new 1990 legislation add on to layers of older disability laws and statutes, some of which had a very different philosophy (Erkulwater 2006; Barnes and Burke, this issue), but one has also to remember that the road to implementation of the ADA was a bumpy one, with a certain degree of backlash. As Linda HamiltonKrieger states, it was already 'vaguely surreal' to see the law pass Congress with overwhelming majorities under a Republican presidency otherwise very adamant against civil rights legislation (Hamilton-Krieger, 2003: 1). The definition of disability in the act was surprisingly very broad and encompassed stigmatising medical conditions such as diabetes or asymptomatic HIV. The very notion of 'reasonable accommodation' was the reflection of a compromise based on the interpretation of what was reasonable for public and private organisations that would bear the costs. Hence the role of the judiciary within an adversarial legal system to do this work of interpretation (Barnes and Burke, 2012) in much the same way as in the case of racial discrimination and affirmative action (Dobbin, 2009), and with similar inequalities (Galanter, 1974) often to the detriment of people with disabilities themselves (Cantor, 2008; Bagenstos, 2009).

Initially there was hope that the concept of structural equality in the ADA would eventually prevail, but subsequent interpretations and rulings have showed time and again that it was far from straightforward. Between 1990 and 2000, the judicial process managed to change the definition of disability that featured in the ADA, so that Congress had to step in again in 2008, passing an Americans with Disabilities Act Amendment Act and reasserting the rights of people with disabilities, but with some modifications of the medical criteria (Emens, 2012). At the same time, the scope of disability in the ADA potentially conflicted with the much more restricted and medical definition that 
had been prevalent in the Social Security Disability Insurance since the postwar era. In order to claim the benefits of Social Security Disability Insurance (SSDI) or Supplemental Security Income (SSI), people had to declare themselves unfit for work, which conflicted with the notion of qualified workers highly prominent in the ADA. In other words, the ADA was more effective for those who were not deemed unable to work.

The first comparative surveys of disability rights and legislation across the world, in the early 2000s, clearly considered that the equal opportunity framework enshrined in the ADA had had a strong - yet uneven - impact on other advanced welfare systems, through the influence of the United Nations and the European Community among others. A true paradigm change seemed to be under way that requalified disability in international law as a subject of human rights, and moved it further from welfare law to civil rights law at national levels. Yet if the nature of change was not denied, the scope of it remained uncertain (Degener and Quinn, 2002). This is not the place to retrace all the intricate processes that may have led to this process of diffusion, but it is however important to ask to what extent this diffusion theory can be confirmed.

To be sure, the discourse of rights and non-discrimination has spread internationally even though different legal systems and cultures of equality could not be expected to translate perfectly a legal framework that met a lot of resistance even in the U.S, that coexisted with limited welfare benefits (Soldatic and Grech, 2014; Heyer, 2015: 89), and that could also challenge other national antidiscrimination policies (Fredman, 2005) ${ }^{1}$. Disability activists worldwide were certainly greatly influenced by the Independent Living Movement in the USA (Barnartt and Scotch, 2001; Fleischer and Zames, 2001) and their achievements exemplified in the ADA, or in visible judicial actions and decisions (Heyer, 2002; Vanhala, 2015). International exchanges and contacts had intensified since the 1980s (Heyer, 2015), with the support of international institutions (Mohanu, 2008; Bregain, 2017) and sometimes without (Stoll, 2015). The 1990s was a significant decade with some 40 nations passing antidiscrimination laws concerning disabilities, as well as visible progress at the regional levels (Degener and Quinn, 2002). And the UN subsequently provided a platform in the process leading to the Convention on the Rights of People with Disabilities in 2006 (Lawson and Gooding, 2005; Arnardóttir and Quinn, 2009), as well as in the expert monitoring of the Convention's ratification that ensued (Fillion et al., 2015; Lang et al., 2011).

Countries such as Germany and France overhauled their legislation at the beginning of the new millennium in a direction that seemed to be coherent with the civil and human rights framework (Winance et al., 2007). Inherited from the WWII period and its aftermath, their previous legislations dated back to the mid-1970s and were based on a restricted, medically-asserted definition of disability (Chauvière, 1980). In the case of France, from the inception, some marginal activist groups (Auerbacher, 1982; Turpin, 2000; Bas, 2017) had criticised a notion of disability that mostly rested on individual impairments rather than on social impediments. The issue of accessibility was already present, but led to mitigated results even if a new law on accessibility of public buildings was passed in 1991 (Ville et al., 2014: 76).

There is no denying the strong climate of activism and change with respect to the legal status of people with disabilities throughout this period. International and regional organisations such as the $\mathrm{WHO}$, the $\mathrm{UN}$, and the $\mathrm{EU}$ were instrumental to bringing disability rights claims to another level, and transforming them into an issue of discrimination and Human rights (Kelemen and Vanhala, 2010; Kelemen, 2011). 
However the definition, classification of disabilities and the construction of appended rights at this level has been a rather contested field. European legal jurisdictions have actually been hesitant as to including in European law the anti-discriminatory principles promoted by the U.N convention (Cantor, 2008; Dammame, 2013). Yet the transfer of disability competence from the Labour Market General Direction to the Justice direction can also be a witness to a deeper institutional transformation that may have important consequences on public policies in the long run (Rowell, 2016).

In addition, the process of ratification of the 2006 UN Convention is still ongoing, along with the first monitoring system whereby countries have to issue an expert report on the state of the convention ${ }^{2}$. In 2016, for the tenth anniversary, 174 countries or regional organisations had ratified (but fewer had signed the optional protocol). France needed no fewer than seven years to complete its own report and the potential, if not legitimate, gap between law in the book and law in practice (Lawson and Gooding, 2005) casts doubts over greater diffusion of these norms in the near future. Article 33 of the UN convention makes it compulsory for states to include representative organisations of people with disabilities in the committees in charge of writing the evaluation report (Raley, 2016). It could be seen as a significant source of empowerment with regard to the definition and review of policies that concern them in the first place. However, this is the strongest measure that the convention pushed forward and its influence rests mostly on 'blame and shame' (Hafner-Burton, 2008). In this respect, the continuous mobilisation of representative organisations will be essential to make sure policies go in the right direction and are actually implemented (Birtha, 2013; Ferri et al., 2017).

Diffusion of new norms is by no means a natural process. It is the result of political will and action. International organisations have played a role and mobilised academic expertise, as they did in the past for the promotion of other guarantees, such as work accident insurance (Moses, 2012). The main publications that address the diffusion of new social or civic rights for people with disabilities are often supported by the same institutions that hold these norms to be universal principles. Jay Rowell, for instance, has showed how the development of antidiscriminatory approaches of employment policies in the EU has been prepared by countless reports and research aiming at measuring the efficiency of quota systems (Rowell, 2016). To some extent, we witness a similar process when it comes to the diffusion of basic rights. Numerous reports originate from institutions dedicated to the promotion of these fundamental rights. (i.e. EU Agency for Fundamental Rights) or are supported or sponsored by them, sometimes in close association with specialised research units (Flynn, 2011). The Galway Center for Disability Law and Policy in Ireland is one good example of the intimate links between academia, expertise and rights militancy that found a good expression in the UN convention. Its director, Gerard Quinn, is a Law professor who, according to his personal page, has been 'a civil servant in the European Commission where he helped change EU policy on disability', 'served on the Irish Government's Commission on the Status of persons with Disabilities (1993-1996) and the Irish Human Rights Commission (2002-2012). $\mathrm{He}$ led the delegation of Rehabilitation International during the negotiations of the United Nations Convention on the Rights of Persons with Disabilities in New York' ${ }^{3}$. The adjunct director, Eilionior Flynn was an expert with the UN committee when the convention was being written. She went on publishing a book and several articles about the content of the text (Quinn and Flynn, 2012; Arstein-Kerslake and Flynn, 2016). She is now a 'member of the Academic Network of European Disability experts Working 
Group to develop a monitoring tool for the European Union Disability Strategy 2010$2020^{\prime 4}$.

If social welfare policies had benefited from the early contribution of sociologists (Brückweh et al., 2012), the politics of civil rights have been promoted - and often evaluated and interpreted - by Law scholars who may have specialised in disability studies. They tend to have knowledge of comparative law and their profile leads them to cross the strict borders of national law. Hence the approach that emphasises diffusion, mostly produced by law scholars who are confident in the capacity of the law to trigger decisive social change (Madsen, 2011), is one of the founding myths of the politics of rights (Scheingold, 1974; Engel and Munger, 2003). It rests on four main assumptions that this themed section would like to question: 1 . The introduction in national laws of antidiscriminatory principles would be a good measure of the diffusion and could help to monitor the gradual conversion of national systems to new international standards; 2. There is a tendency to look at some situations in terms of backwardness that need to be addressed when international norms have not yet had any meaningful impact in those situations; 3 . The transformations of national disability policies would be largely the result of international norms, disregarding the role of specific national/local dynamics and actors; 4 . There is a belief that the progress of civil rights is straightforward and inevitable, that this is the good instrument when other scholars close to social movements question the capacity of this template to become an international norm (Cantor, 2008). According to these scholars, social rights and policies are better forms of protection for people with disabilities than civil rights, and legislations such as the ADA evidence a disappointing record after 25 years, especially with respect to employment (Kruse and Schur, 2003; Maroto and Pettinicchio, 2014).

\section{Putting rights in context}

All these mobilisations and legal activism over the last three decades or more have undoubtedly opened for significant political and legal opportunity structure for people with disabilities and their families, although this opportunity is also obviously uneven between and within countries, and for different individual situations. But there has been a tendency to add up all the new legal provisions, norms and policies in the field as if their intentions and effects were part of the same great coherent movement. Yet if we go back to the initial U.S legislation of 1990, the ADA, several scholars have stressed the fact that its surprising bipartisan nature was in part the result of a normative tension between different conceptions not only of disability, but also of the legitimate role of public institutions with respect to people with disabilities (Erkulwater, 2006; Barnes and Burke, 2014). By shifting the focus from a politics of compensation to civil rights, accessibility and the struggle against discrimination, the ADA and its template could bring together very different interests and political stances behind the banner of promoting rights. For the Republican administration that signed the bill, it could mean the promotion of more integration through the labour market in order to limit the costs of 'passive' welfare. And many disability activists certainly shared the view that barriers preventing access to work should be removed to the largest extent.

But at the same time, there was an insidious contradiction between the new template and the old compensatory model that did not take long to manifest itself: the former put forward the right to work without obstacles and discriminations, whereas the latter more 
or less stressed the need to show an inability to work in order to claim compensation (Barnes and Burke, this issue). This contradiction, and all the judicial interpretations that can flow from it, led to a high number of court cases in which employers prevailed when people called on to the ADA (Diller, 2003). The Supreme Court has tried to overcome this difficulty by stating that ADA and SSDI had different definitions and approaches to disability and that claimants could still have a chance to demonstrate their capacity to fill the essential functions of employment (Boujeka and Amrani Mekki, 2010). There are many other ways than just courts and legal actions for the Law to exert its powerful effects in society and politics. Engel and Munger have elegantly documented how individuals with radically different disabilities and trajectories could develop a sense of entitlement or legitimacy to negotiate with their environment, family, school, employers without ever resorting to the provisions embedded in the ADA (Engel and Munger, 2003; Aucante and Revillard, 2017). But these authors also point to another, deep-seated contradiction in the conception of equality promoted by such a legislation, namely the fact that people have to first prove that they have a disability, facing stigmatisation, in order to claim an equal treatment, or in the case of the ADA, measures that can compensate for a perceived inequality (Engel and Munger, 2003; Nussbaum, 2007). In the U.S, as we see, the issue of layering takes on multiple dimensions: not only do we have a high complexity of the federal and state welfare and civil rights regimes, that Harold Wilensky once described as a 'welfare mess' (Wilensky, 2002), but there are also deep contradictions between both domains in relation to disability and the relevant actors may use these contradictions in order to promote their own, possibly conflicting strategies. Hence the apparent seduction of the North American civil rights template may be slightly tarnished in light of this, and its diffusion/translation to other systems, with the mediation of international organisations, cannot be a straightforward matter.

Needless to say that states and collective actors in the field of disability are not just passive receivers of norms, they have their own traditions, institutions, policies and legal systems to deal with. They are also to different extents parties to the international/regional negotiations of new norms. At the same time, the 'old' infranational politics of disability is often disregarded by scholars in favour of more fashionable international/transnational processes. In many states, federal or not, local regimes exist in all sectors, and in the case of disability it is often especially complex. When it comes to France, local organisations (or branches of national ones) exert the dual role of promoting the interests of people with disabilities and that of managing a certain number of care and sheltered employment institutions, which are not by all means standardised nor equally distributed across the territory (Ville et al., 2014). So when the 2005 Act on Equal rights, chances, participation and citizenship for people with disabilities was adopted, there were high hopes, such as with the U.S ADA. The law gave a 10-year deadline to make all public building finally accessible, a goal that was already prescribed in the previous legislation of 1975. Accessibility turned out to be considered as a universal right beyond the case of people with disabilities ('universal design'). Such a large definition may have led to a paradoxical lack of a detailed roadmap for actors. In spite of progress, the initial deadline for accessibility has not been met and by far. The traditional excuse of the cost in times of public spending contraction has been voiced time and again, along with a variety of other architectural and technical constraints. However for the sake of the argument, it is not just the failings that matter here, but the fact that different conceptions of accessibility still coexist (Larrouy, 2011). There is still a bias that equates accessibility with norms for 
'people with reduced mobility' $(\mathrm{PMR})^{5}$, prominently wheelchair users, and one does not have to go very far to see that a great deal of uncertainty and skepticism still prevails in the professional sectors when it comes to the actual content of the norms. And when technical solutions are implemented, their benefit may be limited in practice if there is no cultural change: many (not all) public buses do have ramps, that can be used for wheelchairs as well as strollers or elderly people, but sidewalks are not always adapted, and a regular bus passenger will rarely witness the use of such devices. It is as though people with disabilities themselves anticipate the evident shortcomings of accessibility and refrain from using the services, leading to their lack of visibility in the public space.

Hence the field of accessibility in France, in spite of the high ambitions formulated in 2005, is still riddled with blatant discriminations, but is also a patchwork of different norms, representations, and sector-specific technical policies that have accumulated since 1975, or even before ${ }^{6}$. The 2005 Act is not just a civil rights law, even though it is inspired by this trend, it incorporates all the compensatory policies and generalises or reframes dispositions that were decided before, such as the obligation for firms and administrations above twenty employees to respect a minimum 'quota' of 6 per cent of their staff with disabilities. This policy is very different from an anti-discriminatory policy, as it revolves around shifting and negotiated definitions of disability, and to reach the target, some firms or administrations are likely to look more intensely for undeclared members of their staff to officially register as disabled persons. In this case, the 2005 Act led to a reinforcement of earlier measures not fully coherent with the civil rights template that is believed to inspire it. Other examples could be mentioned, such as the fact that the new individualised right of compensation $(\mathrm{PCH})$, based on the evaluation of personal needs and the participation of the individual stops at age sixty, drawing an arbitrary line between 'disability' and 'old age dependency' and adding different layers of policies for people who are on each side of the line, even in the case of similar impairments.

Germany, the UK, and Scandinavia feature among the countries that have been most active on the disability legislative front since the mid-1990s, passing several laws and devising successive disability action plans for 'active citizenship' and independent living. These are also countries where reforming welfare state, labour markets and their management has been high on the agenda and led to a profusion of policies and experiments (Roulstone and Barnes, 2005; Lawson, 2008; Tøssebro, 2016). They tend to produce a fair amount of expert reports for the purpose of policy review. The rhetoric of reform and action is important, and if real steps are taken that may improve the condition of citizens, there is no doubt that all this policy activism has also created new layers of regulations and bureaucracy, often under the cover of rationalisation (Pollitt et al., 2004). In the UK, welfare-to-work strategies have triggered frequent changes in relation to disability benefits and rights (Bell and Heitmueller, 2009), and increasing local variations are likely to develop in contexts where decentralisation and contracting out are important. While liberal welfare regimes seem to value the fight against discriminations, especially in the labour market, there is also a real risk that people with disabilities who boast a better work ability might be in a more favourable position. The serious implementation of new civil or social rights is not free of charge, be it for employers of public institutions (Klausen, 1995). At the very least it requires flexibility, training, and (reasonable) accommodation from the employer, if not some guarantee of stability, something that is not highly in fashion in welfare-to-work regimes and in times of unemployment. Indeed these regimes 
do not seem to perform particularly better at providing meaningful and quality jobs and careers than elsewhere in spite of antidiscrimination laws (Lawson, 2008).

There are nonetheless some remarkable shifts, such as the almost complete phasing out of sheltered work in Sweden, and its transformation since 1980 into a new regime dominated by one placement state-owned company, Samhall AB. There is not much available scientific evidence of the impact of this radical change on employer's attitudes and career paths for people with disabilities but, in this case at least, the old system of institutionalised sheltered work has not survived alongside the new one. Besides, the idea of independent living has a long tradition in Scandinavia in relation to old age (Halvorsen et al., 2017), in striking comparison with France where institutions remain strong for seniors and people with disabilities alike, but also with a clear separation between both categories.

There is of course an entire world of different experiences beyond the few examples that this introductory article has tried to address. If the social model and civil rights template have spread elsewhere, especially through the U.N convention, it is likely to have met other entrenched national - sometimes even subnational - regimes of disability. And as two of the articles in this themed review will document, the impact of austerity as well as deep cultural forms of discrimination, such as in the case of indigenous minorities, are dimensions that should not be underestimated. In Japan, as Katharina Heyer shows, there is a feeling of being laggards and missing a legal instrument such as the U.S ADA (Heyer, 2015: 125). Yet Japanese political elites do not seem to have felt the same emergency as activists to promote new rights. Even though Japan signed the UN convention in 2006, it took another eight years to ratify the treaty while national laws were cautiously amended to make space for more reasonable accommodation and less discrimination. The main legal change took effect in April of 2016 and it is therefore too early to judge how it will help to overcome the deep stigma of disability, even though it leaves a lot of space for interpretation of what is actually binding or banned. A few months after, an armed man broke into a home for disabled people near Tokyo and slaughtered nineteen of them in their sleep, harming many others. He confessed to the police that people with disabilities deserved to die. In a majority of countries, however, there is still very little by way of legal status and protection for people with disabilities, with NGOs providing basic support. And the promise of equal rights remains even further away from the reality of people living there.

\section{Conclusion and themed section outline}

The next four articles in this themed section will provide contrasting illustrations of how rights have been translated and possibly hindered in very different national contexts. The issue of policy layering, of tensions and contradictions between the civil/human rights template and other ways to approach disabilities, such as medical and compensatory welfare models will be a central element but not the only one. The disproportionate consequences of austerity policies on people with disabilities, often backed by the same or by other international/regional institutions that may promote the rights of these people, such as the EU, will also be considered. Finally, this section will touch on the interplay between new rights and deeply entrenched forms of discrimination that may affect certain categories within nation states, as in the case of certain minority groups. 
Jeb Barnes and Tom Burke's article goes back to the seminal U.S civil rights legislation, the 1990 Americans with Disabilities Act (ADA), and focuses on the contradictions between the social model it promoted and the persistent medical-compensatory model that other social welfare benefits such as SSDI are based on. The authors show that legal battles and interpretations have not led to a resolution of this 'tensed policy layering' but have instead increased a kind of 'kludgeocracy' - i.e. through ad hoc patches and adjustments - in U.S disability and social policies and severely reduced the transformative ambitions of the ADA in spite of the large bipartisan consensus that produced it.

Pierre-Yves Baudot further develops this concept of layering in his article, in the context of contemporary French disability policy in the wake of the allegedly pathbreaking legislation from 2005. He argues that even though key actors in the process could be influenced by the social model, the ADA or international norms, the law itself was essentially framed in accordance with the specific interests of each party, with a view to reshaping a historic compromise between the State, local authorities and representatives of the disability organisations. The new rhetoric and dispositions do not replace old arrangements, they rather tend to add on to or intertwine in various ways with the existing layers of norms, policies and institutions. They also take part in a larger agenda to reform State and local administration as well as public and social policies. In the land of enshrined 'Republican equality', discriminations remain significant.

Paula Campos Pinto's article deals with the case of Portugal, showing how a wave of new rights for people with disabilities touched the country in the year 2000s, along with the fast ratification of the CRPD by this country. Indeed, the level of ambitions seemed to be high in Portugal but was soon to be crushed by the severe crisis and austerity at the end of this decade. Campos Pinto documents the clash of norms and imperatives flowing from the international and European levels, that is between human and civil rights, on the one hand, and bailout packages for structural adjustment, on the other. She stresses the heavy contrast between the new rights discourses and legislation, and the structural deficit of implementation and resources for people with disabilities. But she also points out that new mobilisations and coalitions have emerged in the fight against austerity and discrimination that also promote counter expertise and monitoring of the enforcement of international norms and of national legislation.

The last article in this themed section takes us all the way to Australia and some of its remote appended territories in the Northern Torres Strait. Karen Soldatic also analyses the dual policy of the Australian government whereby overall spending on disability programs has increased while eligibility criteria have been tightened on a medical basis in order to assert the work capacity of individuals. This results in significant disentitlement as well as higher poverty levels and potentially worsened impairments. But this policy intersects with more deeply entrenched forms of discriminations against some aboriginal minority groups among which disability, unemployment and poverty rates are much higher. Hence the article replaces disability rights and policy in a larger context of global transfers of austerity doctrines but also in the more localised context of indigeneity and internal postcolonialism.

\section{Notes}

1 The concept of discrimination built from situations of disability can conflict with other ways to define discriminations, such as in the case of ethnicity or gender. 
2 States are required to issue a report two years after ratification, then every four years. Many countries - such as France, which was one of the first to ratify - submitted their initial reports after long delays.

3 http://www.nuigalway.ie/cdlp/staff/gerard_quinn.html [accessed 15.07.2017].

4 http://www.nuigalway.ie/research/centre_disability_law_policy/staff/eilionoir_flynn.html [accessed 15.07.2017].

5 One of the leading organisation promoting accessibility in France has been APF, the Association for People with Paralysis.

6 One can think of the ongoing and uncertain 'priority' system in public transports that reserves some seats for war veterans, people with disabilities or the frail elderly.

\section{References}

Arnardóttir, O. M. and Quinn, G. (2009) The UN Convention on the Rights of Persons With Disabilities: European and Scandinavian perspectives, Leiden: Brill.

Arstein-Kerslake, A. and Flynn, E. (2016) 'The general comment on Article 12 of the Convention on the Rights of Persons with Disabilities: a roadmap for equality before the law', The International Journal of Human Rights, 20, 4, 471-90.

Aucante, Y. and Revillard, A. (2017) 'Préface à la traduction française', in D. M. Engel, F.W. Munger, Le Droit à I'Inclusion. Droits et Identité dans les Récits de vie des Personnes Handicapées aux Etats-Unis, Paris, Editions de l'EHESS, 3-15.

Auerbacher, E. (1982) Babette: "Handicapée Méchante", Stock 2.

Bagenstos, S. R. (2009) Law and the Contradictions of the Disability Rights Movement, New Haven: Yale University Press.

Barnartt, S. N. and Scotch, R. K. (2001) Disability Protests: Contentious Politics 1970-1999, Washington D.C.: Gallaudet University Press.

Barnes, J. and Burke, T. F. (2012) 'Making way: legal mobilization, organizational response, and wheelchair access', Law and Society Review, 46, 1, 167-98.

Barnes, J. and Burke, T. F. (2014) How Policy Shapes Politics: Rights, Courts, Litigation, and the Struggle over Injury Compensation, Oxford: Oxford University Press.

Bas, J. (2017) 'Des paralysés étudiants aux handicapés méchants', Genèses, 107, 56-81.

Bell, D. and Heitmueller, A. (2009) 'The Disability Discrimination Act in the UK: helping or hindering employment among the disabled?', Journal of Health Economics, 28, 2, 465-80.

Birtha, M. (2013) 'Nothing about CRPD monitoring without us: a case study on the involvement of the disability movement in policy-making in Zambia', African Disability Rights YearBook, 115-38.

Boujeka, A. and Amrani Mekki, S. (2010) Contentieux et Handicap, Paris: IRJS Editions.

Bregain, G. (2017) Pour une Histoire Transnationale du Handicap. Europe et Amériques, Rennes: PUR.

Brückweh, K., Wetzell, R., Ziemann, B. and Schumann, D. (2012) Engineering Society: The Role of the Human and Social Sciences in Modern Societies, 1880-1980, London, Palgrave Macmillan.

Cantor, J. D. (2008) 'Defining disabled: exporting the ADA to Europe and the social model of disability', Connecticut Journal of International Law, 24, 399-433.

Chauvière, M. (1980) Enfance Inadaptée. L'Héritage de Vichy, Paris: Editions ouvrières.

Chiriacescu, D., Barral, C., Arnould, C., Bouffioulx, E., Castelein, P. and Cote, A. (2015) 'Analyser les procédures et les modalités d'évaluation du handicap à la lumière de la Convention des Nations unies relative aux droits des personnes handicapées : proposition de guide méthodologique', ALTER - European Journal of Disability Research / Revue Européenne de Recherche sur le Handicap, 9, 1, $34-50$

Dammame, J. (2013) 'La socialisation de la notion de handicap en droit de la non-discrimination', Journal Européen des Droits de l'Homme, 4, 836-56. 
Degener, T. and Quinn, G. (2002) 'A survey of international, comparative and regional disability law reform', in M. L. Breslin and S. Yee (eds.), Disability Rights Law and Policy: International and National Perspectives, The Hague: Brill, 3-129.

Diller, M. (2003) 'Judicial backlash, the ADA and the Civil Rights model of disability' in L. Hamilton-Krieger, Backlash Against the ADA. Reinterpreting Disability Rights, Ann Arbor: University of Michigan Press, 62-98.

Dobbin, F. (2009) Inventing Equal Opportunity, Princeton, N.J.: Princeton University Press.

Emens, E. F. (2012) 'Disabling attitudes: U.S. disability law and the ADA Amendments Act', The American Journal of Comparative Law, 60, 1, 205-33.

Engel, D. and Munger, F. (2003) Rights of Inclusion: Law and Identity in the Life Stories of Americans with Disabilities, Chicago: University of Chicago Press.

Erkulwater, J. L. (2006) Disability Rights and the American Social Safety Net, Ithaca, NY: Cornell University Press.

Ferri, D., Halvorsen, R., Hvinden, B., Bickenbach, J., Rodriguez, A., Waldschmidt, A., Sturm, A., Karacic, A. and Dins, T. (2017) 'Implementing the UN CRPD in European Countries. A comparative study on the involvement of organisations representing persons with disabilities', in R. Halvorsen, B. Hvinden, J. Bickenbach, A. Rodriguez, A. Waldschmidt, A. Sturm, A. Karacic and T. Dins (eds.), The Changing Disability Policy System: Active Citizenship and Disability in Europe, London: Routledge, 177-95.

Fillion, E., Barral, C., Cuenot, M. and Roussel, P. (2015) 'Implementation of the United Nations Convention on the Rights of Persons with Disabilities: concepts and indicators for inclusive policies', ALTER European Journal of Disability Research/Revue Européenne de Recherche sur le Handicap, 9, 1-8.

Fleischer, D. Z. and Zames, F. (2001) The Disability Rights Movement: From Charity to Confrontation, Philadelphia: Temple University Press.

Flynn, E. (2011) From Rhetoric to Action: Implementing the UN Convention on the Rights of Persons with Disabilities, Cambridge: Cambridge University Press.

Fredman, S. (2005) 'Disability equality: a challenge to the existing anti-discrimination paradigm?', Disability Rights in Europe: From Theory to Practice, in A. Lawson and C. Gooding (eds.), Oxford, Hart Publishing, 199-218.

Galanter, M. (1974) 'Why the 'haves' come out ahead: speculations on the limits of legal Change', Law and Society Review, 9, 1, 95-160.

Hafner-Burton, E. M. (2008) 'Sticks and stones: naming and shaming the human rights enforcement problem', International Organization, 62, 4, 689-716.

Halvorsen, R., Hvinden, B., Bickenbach, J., Rodriguez, A., Waldschmidt, A., Sturm, A., Karacic, A. and Dins, T. (eds) (2017) The Changing Disability Policy System. Active Citizenship Policy in Europe, Volume I, London: Routledge.

Hamilton-Krieger, L. (2003) Backlash against the ADA. Reinterpreting disability rights, Ann Arbor: University of Michigan Press.

Harpur, P. (2012) 'Embracing the new disability rights paradigm: the importance of the Convention on the Rights of Persons with Disabilities', Disability and Society, 27, 1, 1-14.

Heyer, K. (2002) 'The ADA on the road: disability rights in Germany', Law and Social Inquiry, 27, 4, $723-62$.

Heyer, K. (2015) Rights Enabled. The Disability Revolution, From the US, to Germany and Japan, to the United Nations, Ann Arbor: University of Michigan Press.

Hvinden, B. (2003) 'The uncertain convergence of disability policies in western Europe', Social Policy and Administration, 37, 6, 609-24.

Kelemen, R. D. (2011) Eurolegalism. The Transformation of Law and Regulation in the European Union, Cambridge, Mass.: Harvard University Press.

Kelemen, R. D. and Vanhala, L. (2010) 'The shift to the rights model of disability in the EU and Canada', Regional and Federal Studies, 20, 1, 1-18.

Klausen, J. (1995) 'Social rights advocacy and state building. T. H. Marshall in the hands of social reformers', World Politics, 47, 2, 244-67. 
Kruse, D. and Schur, L. (2003) 'Employment of people with disabilities following the ADA', Industrial Relations, 42, 1, 31-66.

Lang, R., Kett, M., Groce, N. and Trani, J.-F. (2011) 'Implementing the United Nations Convention on the Rights of Persons with Disabilities: principles, implications, practice and limitations', ALTER European Journal of Disability Research/Revue Européenne de Recherche sur le Handicap, 5, 3, 206-20.

Larrouy, M. (2011) L'Invention de l'Accessibilité: des Politiques de Transport des Personnes Handicapées aux Politiques d'Accessibilité de 1975 à 2005, Grenoble, Presses universitaires de Grenoble.

Lawson, A. and Gooding, C. (2005) Disability Rights in Europe: From Theory to Practice, London: Hart Publishing.

Lawson, A. (2008) Disability and Equality Law in Britain: The Role of Reasonable Adjustment, Oxford, Hart Pub.

Madsen, M. (2011) 'Legal diplomacy: law, politics and the genesis of postwar European human rights' in S. L. Hoffmann (ed.), Human Rights in the Twentieth Century: A Critical History, Cambridge: Cambridge University Press, 62-81.

Mahoney, J. and Thelen, K. (2009) Explaining Institutional Change: Ambiguity, Agency, and Power, Cambridge University Press.

Maroto, M. and Pettinicchio, D. (2014) 'The limitations of disability antidiscrimination legislation: policymaking and the economic well-being of people with disabilities', Law and Policy, 1-24.

Mégret, F. (2008) 'The disabilities convention: towards a holistic concept of rights', The International Journal of Human Rights, 12, 2, 261-78.

Mittler, P. (2015) 'The UN Convention on the Rights of Persons with Disabilities: Implementing a paradigm shift', Journal of Policy and Practice in Intellectual Disabilities, 79-89.

Mohanu, V. A. (2008) 'L'européanisation de la question du handicap à travers le Forum européen des personnes handicapées', ALTER - European Journal of Disability Research/Revue Européenne de Recherche sur le Handicap, 2, 1, 14-31.

Moses, J. (2012) 'Contesting risk: specialist knowledge and workplace accidents in Britain, Germany, and Italy 1870-1920', in K. Brückweh, R. Wetzell, B. Ziemann and D. Schumann (eds.), Engineering Society. The Role of the Human and Social Sciences in Modern Societies 1880-1910, London: Palgrave Macmillan, 59-78.

Nussbaum, M. (2007) Frontiers of Justice: Disability, Nationality, Species Membership, Cambridge, Mass., Harvard University Press.

Oliver, M. and Barnes, C. (2012) The New Politics of Disablement, 2nd edn, London: Palgrave Macmillan.

Pierson, P. (2002) 'Coping with permanent austerity: welfare state restructuring in affluent democracies', Revue Française de Sociologie, 43, 2, 369-406.

Pollitt, C., Talbot, C., Caulfield, J., Smullen, A. (2004) Agencies. How Governments Do Things Through Semi-Autonomous Organizations, London: Palgrave Macmillan.

Quinn, G. and Flynn, E. (2012) 'Transatlantic borrowings: the past and future of EU non-discrimination law and policy on the ground of disability', The American Journal of Comparative Law, 60, 1, 2348.

Raley, M. (2016) 'The drafting of Article 33 of the Convention on the Rights of Persons with Disabilities: the creation of a novel mechanism', The International Journal of Human Rights, 20, 1, 138-52.

Roulstone, A. and Barnes, C. (2005) Working Futures?: Disabled People, Policy and Social Inclusion, Bristol, Policy Press.

Rowell, J. (2016) 'L'emploi des handicapés en Europe', Genèses, 103, 96-116.

Sabatello, M. and Schulze, M. (2013) Human Rights and Disability Advocacy, Philadelphia: University of Pennsylvania Press.

Scheingold, S. A. (1974) The Politics of Rights: Lawyers, Public Policy, and Political Change, New Haven: Yale University Press.

Soldatic, K. and Grech, S. (2014) 'Transnationalising disability studies: rights, justice and impairment', Disability Studies Quarterly, 34, 2. 
Stoll, J. (2015) 'The German disability movement as a transnational, entangled new social movement', Moving the Social, 53, 63-86.

Stone, D. A. (1984) The Disabled State, Philadelphia: Temple University Press.

Tøssebro, J. (2016) 'Scandinavian Disability Policy: From Deinstitutionalisation to Non-Discrimination and Beyond', ALTER - European Journal of Disability Research, 10, 2, 111-23.

Turpin, P. (2000) 'Les mouvements radicaux de personnes handicapées en France pendant les années 1970', in F. Paterson, C. Barral, J.F. Stiker, M. Chauvière (eds.), L'Institution du Handicap. Le Rôle des Associations, Rennes: PUR, 315-24.

Vanhala, L. (2015) 'The diffusion of disability rights in Europe', Human Rights Quarterly, 37, 4, 831-53.

Ville, I., Fillion, E. and Ravaud, J-F. (2014) Introduction à la Sociologie du Handicap, Louvain-La-Neuve: De Boeck.

Wilensky, H. (2002) Rich Democracies. Political Economy, Public Policy, and Performance, Berkeley: University of California Press.

Winance, M., Ville, I. and Ravaud, J-F. (2007) 'Disability policies in France: changes and tensions between the category-based, universalist and personalized approaches', Scandinavian Journal of Disability Research, 9, 3-4, 160-81. 